\title{
Reflections on the Pros and Cons of State Regulation*
}

\author{
JOSEPH L. PORKET** \\ Independent scholar
}

\begin{abstract}
Societies need regulation of human behaviour and human social interaction if they want to maintain a system of ordered relationships and, thus, to survive and prosper. Inevitably, it raises the question of who regulates what, when, how, and why on the basis of what title, at what costs, and with what consequences. In modern societies, which are complex systems, an important role is played by state regulation, which may be more or less permissive or restrictive. In any case, it is a source of tensions and conflicts in society. Yet, permissive state regulation is preferable to restrictive. The reason is that by encouraging spontaneity, i.e. individual freedom and self-regulation, albeit within a stable framework of general ex ante rules, it positively contributes to prosperity and development and reduces non-compliance with government-made formal rules, such as second economy activity.
\end{abstract}

Sociologický časopis/Czech Sociological Review, 2002, Vol. 38, No. 3: 311-325

Regulation of human behaviour and human social interaction is a universal feature of societies, whether traditional or modern. In the latter, on account of their size and complex role and subsystem differentiation, it inevitably takes place at different levels, albeit within the framework of state regulation. Consequently, these societies are characterised by a web of formal as well as informal regulation and self-regulation, by a plurality of regulatory systems. And this plurality of regulatory systems is an important source of tensions and conflicts in modern societies.

Currently, state regulation is a hot issue worldwide, both in theory and in practice. After all, it implies a tension between individualism and collectivism, being about the scope of political power and the role of the state in the economy and society, and hence about the degree of autonomy (freedom) enjoyed by the members of society. And since the world is undergoing rapid, wide-ranging, and pronounced change, this tension does not simmer under the surface, but is highly visible in all societies, be they developed, developing, or post-communist.

\section{Rules and commands}

Societies have to regulate human behaviour and human social interaction in order to maintain a system of ordered relationships and, thus, to maximise the probability of their survival and the attainment of their material and non-material objectives in the conditions in

\footnotetext{
* The article is a revised and enlarged version of a paper originally presented at the 5th Conference of the European Sociological Association, Helsinki, Finland, 28 August - 1 September 2001. Its author has doctorates from Charles University, Prague, and the University of London.

** Direct of all correspondence to: Prof. Joseph L. Porket, 26 Crescent Gardens, Eastcote, Ruislip, Middlesex HA4 8TA, United Kingdom, tel/fax 020-8868-7697, e-mail: JLPorket@AOL.com
} 
which they find themselves. In brief, they need regulation if they want to avoid disorder and disintegration and to survive and prosper.

Regulation is a process consisting of the making, application, and adjudication of rules governing human behaviour and human social interaction. A rule is a norm which prescribes or proscribes what a specified category of social actors should or should not do on all occasions of a specified kind or on all occasions without qualification. ${ }^{1}$ Since prescriptions and proscriptions are expected to be observed, the only alternative the addressees have is to break them. A wider choice exists when, instead of prescribing or proscribing, rules express preferences or give permission.

Rules must be distinguished from commands. In contrast to a rule which is a norm applying to a general type of situation, a command is not a norm in this sense. It is an authoritative order addressed to a particular social actor or a particular group of social actors and defining what the addressee(s) should or should not do on a particular occasion. While in some cases it may be rule-based, in others it may break the existing rules, and in still others it may be a substitute for non-existing rules.

To be effective, both rules and commands must be enforceable. Consequently, if it were evident a priori that in practice a particular rule or command would be neither observed nor enforceable, or that the costs of enforcement would be excessively high, it would be politic to refrain from making or applying that rule or from giving that command.

\section{Levels of regulation}

Although the survival and prosperity of modern societies require state regulation, i.e. regulation which concerns the society as a whole, in these societies regulation is not confined to state regulation. Within its framework, formal and/or informal regulation takes place in various spatial social systems (such as subnational units, localities, neighbourhoods, and households) as well as in various functional social systems (such as formal organisations, informal groups, and families). Hence, different levels of regulation and self-regulation are to be found in modern societies, which means that the state is not a monopoly rule-maker and rule-enforcer. ${ }^{2}$

Since different levels of regulation and self-regulation are to be found in modern societies, the individual tends to be simultaneously subject to different and, not infrequently, conflicting regulatory systems, formal as well as informal. This is so because in most cases the individual is simultaneously a member of a number of social systems, including a family, various informal groups and formal organisations, a local community, and a society, each of which has a regulatory system peculiar to it. At the same time, the regulatory systems of face-to-face groups and small local communities may be more restrictive than that of the state.

\footnotetext{
${ }^{1 /}$ In the formulation of F. A. Hayek [1976, 14], 'a rule refers to an unknown number of future instances and to the acts of an unknown number of persons, and merely states certain attributes which any such action ought to possess'.

2/ As put by Michael Laver [1997, 45], 'even in societies dominated by a Leviathan, much day-to-day social interaction is beyond the purview of the state and must perforce be governed along anarchistic lines'.
} 
Regarding specifically the difference between regulation and self-regulation, a social system is a self-regulating system if it can make, apply, and adjudicate the rules governing the behaviour of and the interaction between its members, as well as its behaviour towards and its interaction with its social environment. In contrast, a social system is not a self-regulating system if these rules are imposed on it and enforced from the outside by another social actor. Thus, while in capitalist market economies private firms are self-regulating systems, in socialist command economies state enterprises are regulated systems.

Naturally, there are degrees of regulation and self-regulation. Even in free-market economies private firms' self-regulation is constrained by the legal framework within which they operate. Even societies are not completely self-regulating systems, because state regulation tends to be constrained by international law, treaties, and conventions, as well as by international organisations and transnational actors.

\section{Types of rules}

Irrespective of the level at which regulation and self-regulation take place within societies and between them, several types of rules may be distinguished. ${ }^{3}$ The fundamental distinction is that between formal rules (such as statute laws, by-laws, and charters) and informal rules (such as common law, customs, and conventions). The difference between them lies in that the former are designed, enacted, and formally stated (i.e. made known in written form), whereas the latter come into existence spontaneously, without being designed, enacted, and formally stated.

As the case of traditional societies and that of informal groups in modern societies indicate, informal rules can be effective even in the absence of formal rules. In contrast, formal rules do not put an end to informal rules, as evinced by the persistence in modern societies of traditions, customs, and conventions, as well as by the occurrence in formal organisations of informal rules which support, supplement, obstruct, or supersede formal rules.

Whether formal or informal, rules are either constitutive or regulative. ${ }^{4}$ The former are concerned with the structure of the system and the acquisition and exercise of power or influence, as well as with the system's boundary and membership. If they did not exist, there would be no systems and no institutions, the examples being the institution of property and the institution of the market. The latter are then rules regulating those instances of behaviour and interaction which are independent of them in the sense that they would take place even without them, an example being the rules of the road.

Besides being either constitutive or regulative, formal and informal rules are either permissive or restrictive concerning social actors' behaviour and interaction, including their goals and means. Although explicitly or implicitly both simultaneously prescribe what social actors should do and proscribe what they should not do, permissive rules are by their nature process-orientated and, hence, goal-independent, whereas restrictive rules are by their nature goal-orientated and, hence, goal-dependent.

\footnotetext{
${ }^{3 /}$ On the typology of rules see e.g. A. J. M. Milne [1988, 51-58] and Francis Fukuyama [2000].
}

4/ Douglass C. North speaks about constitutional rules and operating rules [1981, 203]. 
Since rules can be more or less permissive or restrictive, they may be located on a continuum ranging from highly permissive (which confine themselves to defining broad parameters within which social actors are free to make their own choices) to highly restrictive (which are highly specific as to both goals and means). The more permissive they are, the higher the autonomy of social actors, and vice versa. The more restrictive they are, the more they tend to shade into commands.

Not only rules, but regulatory systems, too, are more or less permissive or restrictive. Since individuals tend to be simultaneously members of a number of social systems, they are simultaneously subject to a number of regulatory systems, some more permissive, others more restrictive. In this respect, the distinction between compulsory and voluntary membership is of importance: when their membership in a particular social system is compulsory, individuals have no choice but to be members, irrespective of how permissive or restrictive it is; in contrast, when their membership in a particular social system is voluntary, their choice depends less on how permissive or restrictive it is and more on how it contributes to the satisfaction of their needs and wants, to their survival and prosperity.

\section{State regulation}

Like regulatory systems in general, also the state as a regulatory system can be more or less restrictive or permissive. How restrictive or permissive it is, depends on the extent and intensity of state regulation. At the same time, the extent and intensity of state regulation may vary from one sphere of human behaviour and human social interaction to another. Thus, the extent and intensity of state regulation may be located on a continuum ranging from highly restrictive in all spheres of human behaviour and human social interaction at one extreme to highly permissive in all spheres of human behaviour and human social interaction at the other.

When state regulation is highly restrictive in all spheres of human behaviour and human social interaction, the degree of autonomy (freedom) enjoyed by the members of society is low and their dependence on the state high. In contrast, when state regulation is highly permissive in all spheres of human behaviour and human social interaction, yet keeps anarchy in the sense of a state of disorder at bay, the degree of autonomy (freedom) enjoyed by the members of society is high, allowing self-assertion (the pursuit of self-interest, choice), but also requiring self-reliance.

Irrespective of its extent and intensity, state regulation is a source of tensions and conflicts in society, because while some members of society may favour the existing extent and intensity of state regulation, others may favour its expansion either generally or in a particular sphere, and still others may favour its contraction, again either generally or in a particular sphere. For example, one British report distinguished five categories of voters. Depending on their attitudes towards economic and personal freedom, voters consisted of conservatives (who favoured economic freedom but wanted state regulation of personal freedom, i.e. of individual choice in moral and social issues), socialists (who distrusted economic freedom but favoured personal freedom), authoritarians (who favoured neither economic nor personal freedom), libertarians (who favoured both economic and personal freedom), and centrists (who stood in the middle of the range on both economic and personal freedom) [Blundell and Gosschalk 1997, David Smith 1997, 40]. 
Going back to the differences in and consequences of the extent and intensity of state regulation, permissive state regulation is conducive to the autonomy (freedom) of the members of society and, hence, to self-regulation as well. Yet, per se it does not determine whether and how social actors will use their autonomy (freedom): while on the one hand they need not actually make full use of all the opportunities available to them, on the other they may show lack of self-restraint and take undue advantage of others. And while it is conducive to self-regulation, simultaneously it cannot dispense with it, albeit on condition that self-regulation is constrained by conventions, customs, and traditions and does not endanger society's cohesion and performance.

Restrictive state regulation, in contrast, circumscribes the autonomy (freedom) of the members of society and, hence, also self-regulation. Being extensive and intensive, it tends to have an adverse impact on flexibility, innovation, and efficiency; to increase the costs connected with rule-making, rule-application, and rule-adjudication; and to lessen respect for rules and contribute to covert and overt non-compliance on the part of the members of society, one reason for non-compliance being compliance costs. Moreover, when state regulation is extensive and intensive, rules are prone to be specific rather than general, to suffer from inconsistencies, and to breed uncertainty because, besides often creating confusion, they have to be frequently modified or changed in response to both changing conditions and contingencies.

In sum, while permissive state regulation is a sign that the state is process-orientated, restrictive state regulation is a sign that the state is goal-orientated in the sense of being concerned with an end-state or final outcome. To use Giovanni Sartori's terminology, the former is characterised by the rule of law, whereas the latter is characterised by the rule by laws, which nears, albeit in disguise, the rule by men [Sartori 1987]. Expressed differently, the latter is characterised by an incessant flow of ad hoc (discretionary) political and bureaucratic decisions and ad hoc rules.

When state regulation is extensive and intensive and it becomes apparent that it neither works nor can work as expected, calls for deregulation are likely to materialise and grow. Its purpose is to increase the autonomy (freedom) of the members of society by curtailing government intervention in the economy and society. This requires reducing the existing amount of rules and/or changing the content of the existing rules, as well as putting a check on ad hoc political and bureaucratic decisions. In brief, this requires substituting general and abstract rules for specific and ad hoc rules or, in other words, process-orientated (goal-independent) rules of conduct for goal-orientated (goal-dependent) rules.

Besides these measures, deregulation may need a revision of the established rules governing rule-making. The need arises when the established rules governing rule-making enable a proliferation of ad hoc rules, so that goal-driven governments are able arbitrarily to enact ad hoc rules while nominally abiding by the established rules of rule-making.

\section{Rule enforcement}

Rules are expected to be observed, not broken. In the real world, though, they are not always observed, but often intentionally or unintentionally broken, sometimes even by the rule-makers themselves. In modern societies, which are state societies, this applies to rules at any level of regulation and, consequently, also to legal and bureaucratic rules. 
If rules are to be observed by their addressees, they must be enforced, and their enforcement is to be achieved by the use of both positive sanctions (and the promise thereof) and negative sanctions (and the threat thereof). In other words, to encourage as well as reward compliance with rules on the one hand and to deter as well as punish non-compliance with rules on the other, rule-enforcement has to rely on a combination of physical, material, and symbolic means.

Although rules must be enforced if they are to be observed, some are more flexible (i.e. less rigorously applied and enforced) than others. Two main approaches to rule-enforcement may be distinguished, namely, the zero-tolerance approach (which punishes any violation of rules, however slight) and the zone-of-indifference approach (which tolerates minor violations of rules). The more extensive and intensive state regulation, the more problematic is the zero-tolerance approach and the more necessary is the zone-of-indifference approach.

Whether flexible or inflexible, rules may permit or require exceptions, exempting certain social actors from compliance with them. According to Robert B. Edgerton, it is possible to identify four general categories of rule exceptions: exceptions based on temporary conditions, such as temporary incapacity; exceptions arising from a specific status, such as infancy, disability, or old age; exceptions connected with special occasions, such as harvest or initiation rituals or funerals; and exceptions that apply only in certain settings, such as sanctuaries [Edgerton 1985].

Since government-made rules must be enforced if they are to be observed, effective rule-enforcement presupposes that rules are enforceable and that the government, besides being determined to enforce them even in the face of opposition and resistance, has at its disposal the requisite physical, material, and symbolic resources. At the same time, the less compliance with rules is based on normative grounds (commitment), the greater the importance of material and physical means in rule-enforcement. Yet, compliance based on utilitarian (calculative, instrumental) grounds is more fragile than that based on commitment, because it has a tendency to decline when the performance of the state declines, when its ability to gratify and enforce falls.

Thus, rule-making and rule-enforcement incur costs, which have to be covered by the revenue extracted by the state from the economy by means of taxation, direct and indirect. Inevitably, the more extensive and intensive state regulation, i.e. the more formalised and bureaucratised the economy and society, the more revenue the state needs and has to extract from the economy. In any case, revenue extraction incurs extraction costs, depends on the state's not unlimited extractive capabilities, and can give rise to tax avoidance (which remains within the law), tax evasion (which breaks the law), and other forms of tax resistance (such as delays in tax payment or tax revolts).

It follows that state regulation should take into consideration not only its expected short-term and long-term as well as material and non-material benefits, but also its expected short-term and long-term as well as material and non-material costs, trying to maximise the former and minimise the latter. It follows, too, that tolerance of non-compliance is likely to increase as the expected costs of rule-enforcement increase. 


\section{Constraints on state regulation}

The extent and intensity of state regulation depend on the orientation of government, on whether it is process-orientated or goal-orientated in the sense of being concerned with an end-state or final outcome. In any case, though, there are limits to effective state regulation, so that the state is constrained in what it can do and attain.

Besides being constrained by the available resources and the costs of rule-making and rule-enforcement, effective state regulation is further constrained by three major factors. The first is universally valid economic and other laws, which no state regulation can put out of operation. The second is the existing political, economic, and civic structures: if they are to be preserved, state regulation must not encroach on them. And the third is the values of society: the more state regulation is at odds with the values of society, the greater the likelihood of covert and overt non-compliance. Hence, there is an important difference between effective state regulation and nominal state regulation. The difference lies in that the former leads to compliance with the designed, enacted, and formally stated rules, whereas the latter does not. That is to say, while the former regulates human behaviour and human social interaction, the latter fails to do so.

Yet although it is easier to make rules than to enforce them, even rule-making faces constraints. One of them is political constraints: by definition, rule-making is politically less constrained in authoritarian political systems than in democratic ones, and in democratic ones it is politically less constrained in the case of one majority party government than in the case of a coalition or a minority government. ${ }^{5}$

In democratic political systems, another constraint on rule-making is the constitution, which defines the parameters within which rule-making is to take place. In other words, constitutional rules are designed to control, inter alia, the exercise of political power and, consequently, rule-making as well. For that reason, they are also intended to be more costly to amend, modify, and replace than are operating rules. ${ }^{6}$ A further constraint on rule-making in democratic political systems is judicial review, which means that courts are explicitly or implicitly empowered to invalidate laws and administrative actions: while in the case of constitutional review they rule on the constitutionality of laws and regulations, in the case of administrative review they rule on the legality of administrative actions. Besides, in democratic political systems rule-making is affected by the demands and activity of pressure groups ${ }^{7}$ and social movements, ${ }^{8}$ as well as by public opinion and the mood of the time. They can block change in state regulation on the one hand and enforce it on the other. Ultimately, the state may become a captive of narrow (special, sectional) interests that either defend the status quo or press for change.

\footnotetext{
${ }^{5 /}$ Some propositions concerning the impact of the electoral system and the type of government on comprehensive public sector reforms and market-oriented reform policies can be found in Harrinvirta [2000, 143-147].

6/ On flexible and rigid constitutions see Arend Lijphart [1999, 218-223].

7/ See e.g. J. L. Porket [1998, xvi-xvii, 36-37, 116-117 and 255].

${ }^{8 /}$ According to Robert O'Brien et al. [2000, 12], social movements are anti-systemic and rely on mass mobilisation. However defined, though, they should be regarded as a subset of norm-setting pressure groups.
} 


\section{Compliance and non-compliance}

Although there are limits to effective state regulation, governments may become obsessed with regulation. That is to say, they may develop a regulatory mentality, characterised by a belief that they are the best judges of what is good for society and that, by means of regulation, they can solve any problem and attain any political, economic, social, and cultural objective. The inevitable result of this belief in their omniscience and omnipotence is then extensive and intensive state regulation.

Being inimical to spontaneity, extensive and intensive state regulation noticeably circumscribes the autonomy (freedom) of the members of society. At the same time, it gives rise to uncertainty, because it has to be undergoing perpetual change. The reason is that whenever the existing rules do not produce the officially desired outcomes, on principle the remedy is sought either in their modification or in their replacement by new ones, not in their relaxation or repeal. ${ }^{9}$

Whatever the extent and intensity of state regulation, it incurs costs which must be covered by the revenue extracted by the state from the economy by means of taxation, direct and indirect. In addition, though, state regulation can impose costs on the economy by forcing economic actors (private firms in the first place) to take on certain duties, such as to clean the environment, introduce particular safety measures, maintain specific product standards, pay a minimum wage, provide benefits to employees, and collect taxes on behalf of government. ${ }^{10}$

In any case, state regulation affects all spheres of human behaviour and human social interaction. In the economic sphere, for instance, it has an impact on productivity, competitiveness, competition, profitability, hiring and firing, unemployment, prices, and consumers' choice. Outside the economic sphere, it has an impact on, inter alia, access to information, communication, political activity and processes, marriage, divorce, provision of health care and education, social inclusion and exclusion, individuals' opportunities, privileges, crime, and immigration.

For society, the impact of state regulation may be beneficial or harmful, depending on its extent and intensity. In principle, state regulation is beneficial if it contributes to economic, political, social, and cultural development by being process-orientated and, thus, allowing spontaneity, albeit within the framework of general and abstract rules. In contrast, state regulation is harmful if it retards economic, political, social, and cultural development by being goal-orientated and, thus, putting fetters on spontaneity.

Yet, whether process-orientated or goal-orientated, state regulation is a source of tensions and conflicts in society. They arise because the interests of the members of society differ and because these interests determine attitudes towards the existing and the desired extent and intensity of state regulation as well as towards compliance and non-compliance with the existing rules. At the same time, the choice between compliance and non-compliance is affected by the perception of their costs, which need not be exclusively economic.

By definition, goal-orientated state regulation is more conducive to covert and overt non-compliance than process-orientated state regulation. The reason is that the former, be-

\footnotetext{
9/ As to specifically command socialism see J. L. Porket [1989, 186].

10/ Some estimates of the costs imposed on business by government regulation in a variety of countries and contexts are quoted by Graham Bannock [2001, 2-4].
} 
ing extensive and intensive, is likely not only to be detached from reality, but also to suffer from inconsistencies, so that the observance of one rule precludes the observance of another. As a result, in order to avoid paralysis, at least some of the rules applying to particular situations must be broken. This means that goal-orientated state regulation contributes to the emergence and persistence of a culture of rule-breaking.

\section{Pitfalls of state regulation}

It follows from the foregoing that goal-orientated state regulation can fail to attain its objectives and/or produce unintended consequences. In other words, it can fail to solve existing problems, exacerbate them, and/or create new ones. Empirical evidence is not difficult to come by, as demonstrated by the selected cases presented below.

One example of the failure of state regulation is Prohibition in the United States. In this liberal democracy, a considerable proportion of the population had always deplored the use of alcohol. Under their pressure, the production, sale, and transport of alcohol were outlawed between 1920 and 1933. However, the ban did not stop people drinking. It merely drove them underground, i.e. to break the law, and gave rise to organised crime engaged in smuggling, illicit distilling, and bootlegging. These activities, not surprisingly, involved widespread corruption as well as the use of violence. ${ }^{11}$

Another example is the case of the communist systems established in the former Soviet-bloc countries. As variants of totalist authoritarianism characterised by authoritarian politics and political control over the economy and society, they were highly formalised and bureaucratized. Nevertheless, they had an informal dimension too, which was an unintended product of the formal system and deviated from it, in some respects complementing it, in others eroding it. Among its elements was the second economy, brought about by the bureaucratisation of the economy and chronic shortages affecting consumers and state enterprises alike.

Illegal second economy activities were not confined to communist systems, though. They are to be found in any established modern economic system, irrespective of its type. In capitalist market economies, for instance, they have increased considerably since 1960, their major causes being the tax burden, the complexity of the tax system, and restrictive state regulation. They are also far from absent in the developing countries, ${ }^{12}$ as well as in the post-communist ones.

The last example concerns contemporary Britain. Since the 1997 general election, the Labour government has been obsessed with regulation. New regulatory measures have imposed additional compliance costs on business, estimated to reach $Ł 15$ billion by January 2002 [Smith 2001]. ${ }^{13}$ They have also imposed performance targets on the health

\footnotetext{
11/ A less known case concerns off-course betting in Britain, which did not disappear between 1853 and 1961, although legally prohibited.

${ }^{12 /}$ In the developing world, according to some estimates, 50-75 per cent of all working people participate in the second economy, the size of which amounts to between one-fifth and more than twothirds of the total economic output of the Third World. [Hernando de Soto 2000, 75]

${ }^{13 /}$ For estimates of the total additional cost to business, including tax increases, see Nicholas Boys Smith [2001].
} 
service, social services, education, the police, and local government. Besides, they were becoming a threat to the effectiveness of the armed forces as well as to individual freedom.

Despite the sharp increase in red tape, by mid-2001 Britain was still regarded as having a more business-friendly environment than other European Union countries. Nevertheless, since 1997 its global competitiveness has been gradually falling. There have been troubles with targets, too, arising from their impact on the behaviour of individuals and organisations: targets may encourage cheating and rule-breaking, adversely affect performance in areas not covered by them, and reduce responsiveness to real problems. ${ }^{14}$

A number of factors have contributed to the proliferation of rules and targets. They have included the government's goal-orientation; its naive belief in the inherent effectiveness of rules and targets and, hence, of centralisation and micromanagement; its petty riskaversion manifesting itself in, inter alia, its safety fanaticism; and the influence of regulation-demanding pressure groups and public opinion.

\section{Between Leviathan and anarchy}

The probability that goal-orientated state regulation will fail to attain its objectives and/or produce unintended consequences increases the more extensive and intensive it is. This means that there are limits to effective state regulation, to political control over the economy and society. Yet, even when state regulation fails to attain its objectives and/or produces unintended consequences, it still can be effective enough to keep anarchy (in the sense of a state of disorder $)^{15}$ at bay and to maintain a system of ordered relationships.

Situations can arise, though, when effective state regulation is practically absent either because government is unable and/or unwilling to enforce the enacted formal rules, or because the collapse of the hitherto established political and economic system has created a temporary systemic vacuum. Predictably, such situations tend to bring about an increase in self-regulation as well as an expansion of both the household economy and the second economy, and urgently call for effective (not just nominal) state regulation, for the rule of law.

In the last decade of the twentieth century, a tempory systemic vacuum came into being in the former Soviet-bloc countries as a result of the collapse of communism therein. As already noted, the communist systems established in these countries were characterised by a state regulation that was highly restrictive in all spheres of human behaviour and human social interaction. Yet, they did not escape non-compliance (albeit mostly covert) in the form of, inter alia, productive second economy activity, corruption, patronage, and informal networks. ${ }^{16}$

\footnotetext{
14/ To give an example, the performance targets set by the Strategic Rail Authority have encouraged train operators to stretch journey times in their timetables to minimize the risk of trains arriving late, so that some journeys now take longer than they did 100 years ago. [The Economist, 9 June 2001, p. 47.]

${ }^{15 /}$ In the parlance of libertarianism and anarchism, though, the term 'anarchy' is merely another name for spontaneity. The former argues that the role of the state should be confined to the protection of individual liberty and private property, while the latter advocates the abolition of the state and its replacement by a free and spontaneous cooperation among individuals, groups, regions, and nations.

16/ Patronage and informal networks in the party-state are the subject-matter of a special issue of [Contemporary European History, 2002). See also Alena V. Ledeneva [1998].
} 
Basically, the temporary systemic vacuum brought about by the collapse of communism meant an anarchic situation in which the hitherto established system of state regulation was not functioning any more, but an alternative system of state regulation still was not in place. Consequently, it was far from clear which government-made formal rules were in force, and this uncertainty inevitably had an adverse impact on both rule-enforcement and law-abidance. Thus, one of the problems facing the post-communist countries right from the beginning was to build an effective system of state regulation that would put an end to the existing systemic vacuum and ensure stability.

Since state regulation is a question of the scope of political power and the role of the state in the economy and society, the problem was to define both. And since effective state regulation is not possible without rule-makers and rule-enforcers, the problem implied defining the structure of political power as well. In sum, the problem was to define formal rules governing the behaviour of and interaction between social actors in post-communist societies, including the acquisition, exercise, and accountability of political power, revenue extraction and spending by government, the allocation of resources and tasks, and the distribution of outcomes.

Not surprisingly, in practice some post-communist countries have dealt with this problem more successfully than others. That is to say, while some already have built an effective system of state regulation compatible with democracy and market capitalism, others have failed to do so hitherto. ${ }^{17}$ Among the latter, the most prominent stragglers have been Russia, ${ }^{18}$ Ukraine, and Belarus, as well as Bulgaria and Romania.

A number of intrasocietal (country-specific) and extrasocietal factors have encouraged or retarded the building of an effective post-communist system of state regulation and affected the extent and intensity of state regulation. To name a few, the former have included post-communist governments' determination, orientation, policies, and capabilities, the party and electoral systems, the influence of pressure groups and social movements, the values of society, voters' manifested preferences, and the mood of the time, while the latter have included, at least in the case of the applicants for membership in the European Union (EU), the EU's requirement that the applicants implement a prior wideranging harmonisation of their legal standards and institutions with those prevailing in the EU.

Even when the post-communist countries have succeeded in building an effective system of state regulation, though, they have not been able completely to eliminate non-compliance with government-made formal rules. Consequently, they have not been able to get rid of informal economy activity (fraud, tax evasion, corruption, organised crime, ${ }^{19}$ and so on) either. However, its extent has varied considerably from one

\footnotetext{
17/ See e.g. Adrian Karatnycky [1997].

${ }^{18 /}$ In post-communist Russia, for instance, 'The problem is not an absence of legislation, but an absence of enforcement and an associated absence of expectations for the rule of law to be established in the near future' [Stefan Hedlund, 1999, 261].

19/ The bearers of organized crime are known as mafias. Two types of mafia organisations may be distinguished, namely, the mafia as a profit-maximising firm and the mafia as a government. The latter plays a rule-making role in a given territory, be it geographically or functionally defined, and imposes regulations on legal and/or illegal firms. Thus, it provides a rule of law of a sort and a system of dispute settlement, i.e. a relatively stable framework for economic activity.
} 
post-communist country to another and, within the same post-communist country, over time. $^{20}$

While it is likely that in the post-communist countries the extent of informal economy activity will contract somewhat in the future, it is unlikely that they will see this marketed albeit illegal and unrecorded economic activity to disappear totally. After all, the informal economy is a universal feature of modern (state) societies as well as a cross-system phenomenon.

\section{Conclusion}

Whether they are traditional or modern, societies need regulation of human behaviour and human social interaction if they want to maintain a system of ordered relationships and, thus, to survive and prosper. Hence, regulation matters. More specifically, it matters who regulates what, when, how, and why on the basis of what title, at what costs, and with what consequences.

In modern societies, one of the rule-makers and rule-enforcers is the state. This raises the important question of its role in the economy and society at large, because the role it actually plays in the economy and society has an impact on the degree of autonomy (freedom) enjoyed by the members of society and, at the same time, is a source of tensions and conflicts in society. These tensions and conflicts arise from differences in social actors' interests. Social actors, be they individuals or social systems, are motivated first and foremost by their own interests, and their pursuit of self-interest then determines their attitudes towards the role of the state in the economy and society at large and, thus, towards the extent and intensity of state regulation. And since social actors' interests differ, also their attitudes towards the extent and intensity of state regulation differ.

As a result of these tensions and conflicts, the extent and intensity of state regulation undergo change over time. In fact, over the last five centuries modern societies have experienced regulation-deregulation cycles, with regulation-orientated periods (characterised by governments obsessed with regulation) followed by spontaneity-orientated periods (characterised by governments showing regulatory restraint) and spontaneity-orientated periods giving way to regulation-orientated periods.

While temporary fluctuations in the extent and intensity of state regulation tend to be triggered off by contingencies such as war or natural disasters, regulation-deregulation cycles reflect mood swings (change in preferences) brought about by social actors' perception of a widening gap between their expectations and reality. Regulation-orientated periods begin to come to their end when the enforcement costs of state regulation begin to exceed its benefits, when state regulation begins to fail to attain its objectives, and when non-compliance begins to be common rather than rare. In contrast, spontaneity-orientated periods begin to

\footnotetext{
${ }^{20 /}$ On the size of the second economy in the post-communist countries between 1989 and 1995 see European Bank for Reconstruction and Development [Transition Report 1997, p. 74, and Mária Lackó, 2000, 117-149]. On the level of corruption in selected post-communist countries see [Richard Rose, William Mishler and Christian Haerpfer, 1998, 221, Table 10.1], and on the level of corruption in developed, developing, and post-communist countries see Vito Tanzi [1998, 559-594].
} 
come to their end when state regulation begins to be regarded widely as a panacea and when security (protection against any contingency) begins to be valued more than freedom.

Neither regulation-orientation nor spontaneity-orientation is peculiar to a particular type of modern political system. That is to say, the extent and intensity of state regulation do not depend on whether the established political system is authoritarian or democratic. Both can be either restrictive or permissive, albeit with the proviso that authoritarian political systems are by their nature always restrictive in the political sphere.

Although the extent and intensity of state regulation can give rise to tensions and conflicts in any type of modern political systems, in democratic political systems they can also give rise to a tension between democratic procedures of governance and goal-attainment. The reason is that in these systems the goal-orientation of the elected government can lead to the subordination of democratic procedures of governance to goal-attainment, to an authoritarian, stealthy, or control-freak style of governance which does not hesitate to discard those democratic procedures of governance that inhibit goal-attainment.

In contemporary societies, not surprisingly, state regulation continues to play an important role in all spheres of human behaviour and human social interaction. Yet, and again not surprisingly, governments are not monopoly rule-makers and rule-enforcers. Whether elected or not, they inevitably have to compete with a wide range of other rulemakers and rule-enforcers, intrasocietal as well as extrasocietal, who act as constraints on their rule-making and rule-enforcement.

Both permissive and restrictive state regulation continue to have their ardent proponents and opponents, with the proponents of state regulation demanding more state regulation and the opponents of state regulation demanding less state regulation. However, since about the mid-1990s demands for more state regulation, for activist government, have been growing, partly as a response to economic liberalisation and globalisation. ${ }^{21}$ In other words, belief in the inherently beneficial effects of state regulation remains widespread in many societies. $^{22}$ At the same time, most governments still have a penchant for incessant meddling, tinkering, and regulative activity, and an aversion to spontaneity and, thus, to deregulation.

Yet there are compelling reasons for encouraging spontaneity, i.e. individual freedom and self-regulation, albeit within a stable framework of general ex ante rules. Modern societies are complex systems. Moreover, the world is currently undergoing rapid, wideranging, and pronounced change, which creates problems calling for a solution. But different social actors face in different circumstances different problems which need tailored solutions. Therefore, problems should be solved at the level at which they arise by those who experience them and have an interest in their effective and efficient solution as well as the requisite knowledge and capabilities.

Since extensive and intensive state regulation stifles spontaneity, it inevitably retards societal development, both economic and non-economic. On top of that, it can fail to attain its objectives and/or produce unintended consequences, one of them being covert and

\footnotetext{
21/ Globalism's challengers are discussed by Manfred B. Steger [2002], who makes a distinction between left and right anti-globalists.

221 According to Kate Hudson [2000, 16], 'the new, post-1989, anti-welfare face of capitalism is far from being welcome to a very large part of the population'. On contemporary economic anti-liberalism see David Henderson [2001].
} 
overt non-compliance with government-made formal rules. Expressed differently, it can fail to solve existing problems, exacerbate them, and/or create new ones.

At the same time, state regulation takes place in a world which is interdependent, made up of nation-states pursuing their own interests, and differentiated in economic, political, social, and cultural terms. This diversity of national interests and conditions constitutes a constraint on the extent and intensity of effective supranational (regional and global) regulation, even in the case of the European Union with its superstate tendency. Just as individual societies, the world too is characterised by a web of formal and informal regulation and self-regulation, by a plurality of regulatory systems.

JosePh L. Porket has been associated with the Prague School of Economics, Brunel University, and St. Antony's College, Oxford. His numerous publications deal mostly with communism and post-communism and include Modern Economic Systems and Their Transformation (Macmillan, 1998) and Unemployment in Capitalist, Communist and Post-Communist Economies (Macmillan, 1995).

\section{References}

Bannock, Graham 2001. 'Editorial: Controlling Regulation', Economic Affairs, vol. 21, no. 2 (June), p. 2-4.

Blundell, J., B. Gosschalk 1997. Beyond Left and Right: The New Politics of Britain. London: The Institute of Economic Affairs, IEA Working Paper No. 1

Boys Smith, Nicholas 2001. No Third Way: Interfering Government and Its Cost to Business. London: Politeia.

Contemporary European History 2002, vol. 11, part 1 (February)

De Soto, Hernando 2000. The Mystery of Capital: Why Capitalism Triumphs in the West and Fails Everywhere Else. London: Bantam Press.

Economist, 9 June 2001.

Edgerton, R.B. 1985. Rules, Exceptions, and Social Order. Berkeley: University of California Press.

Francis Fukuyama 2000. The Great Disruption: Human Nature and the Reconstitution of Social Order. London: Profile Books, Chapter 8.

Harrinvirta, Markku Olavi 2000. Strategies of Public Sector Reform in the OECD Countries: A Comparison. Helsinki: The Finnish Society of Sciences and Letters.

Hayek, F. A. 1976. The Mirage of Social Justice. London: Routledge \& Kegan Paul, 14.

Hedlund, Stefan 1999, Russia's 'Market' Economy: A Bad Case of Predatory Capitalism. London: ULC Press.

Henderson, David 2001. Anti-Liberalism 2000: The Rise of New Millennium Collectivism. London: The Institute of Economic Affairs, Occasional Paper 115.

Hudson, Kate 2000. European Communism since 1989: Towards a New European Left? Basingstoke: Palgrave.

Karatnycky, Adrian 1997. 'Introduction: Political and Economic Reform in East Central Europe and the New Independent States: A Progress Report', in Adrian Karatnycky, Alexander Motyl and Boris Shor (eds.), Nations in Transit 1997: Civil Society, Democracy and Markets in East Central Europe and the Newly Independent States. New Brunswick: Transaction Publishers. 
Lackó, Mária 2000. "Hidden Economy - An Unknown Quantity? Comparative Analysis of Hidden Economies in Transition Countries, 1989-95”, Economics of Transition, vol. 8, no. 1, p. 117-149.

Laver, M. 1997. Private Desires, Political Action: An Invitation to the Politics of Rational Choice. London: SAGE Publications.

Ledeneva, Alena, V. 1998. Russia's Economy of Favours: Blat, Networking and Informal Exchange. Cambridge: Cambridge University Press.

Lijphart, Arend 1999. Patterns of Democracy: Government Forms and Performance in Thirty-Six Countries. New Haven: Yale University Press.

Milne, A.J.M. 1998. Ethical Frontiers of the State: An Essay in Political Philosophy. Basingstoke: Macmillan.

North, Douglass C. 1981. Structure and Change in Economic History. New York: W.W. Norton \& Company.

O’Brien, Robert, et al 2000. Contesting Global Governance: Multilateral Economic Institutions and Global Social Movements. Cambridge: Cambridge University Press, p. 12.

Porket, J. L. 1998. Work, Employment and Unemployment in the Soviet Union. Basingstoke: Macmillan, p. 186.

Porket, J. L. 1989. Modern Economic Systems and their Transformation. Basingstoke: Macmillan.

Rose, Richard, William Mishler and Christian Haerpfer 1998. Democracy and Its Alternatives: Understanding Post-Communist Societies. Cambridge: Polity Press.

Sartori, G. 1987. The Theory of Democracy Revisited. Chatham, New Jersey: Chatham House Publishers.

Smith, David 1997. The Ascent of Political Man, The Sunday Times, 7 December.

Smith, David 2000. Labour's Red Tape Strangles Economy, The Sunday Times, 6 May.

Steger, Manfred B. 2002. Globalism: The New Market Ideology. Lanham, Maryland: Rowman \& Littlefield Publishers, Chapter 4.

Tanzi, Vito 1998. “Corruption Around the World: Causes, Consequences, Scope, and Cures”, IMF Staff Papers, Vol. 45, No. 4 (December), pp. 559-594.

Transition Report 1997, Enterprise Performance and Growth. London: European Bank for Reconstruction and Development. 
